\title{
The Sustainable Development Practices Role and Transformational Leadership: Interaction and Impact on the Financial Performance
}

\author{
Khaled Jundi ${ }^{1}$, Anas Ghazalat ${ }^{2, *}$ and Sofri Yahya ${ }^{1}$ \\ ${ }^{1}$ Graduate School of Business, Universiti Sains Malaysia, Malaysia \\ ${ }^{2}$ Faculty of Business, Arab Open University, Jordan
}

\begin{abstract}
The purpose of this study is to explore the direct relationship between sustainable development practices and financial performance. It also examines the moderating effect of transformational leadership approach on this relationship. Using primary data sources, this study presents a case study of the Jordanian construction industry. A survey of 290 managing directors or his appointed representative for 1113 construction companies in Jordan. Data were collected from October 2017 until April 2018. The multiple regression analysis and hierarchical multiple regression analysis are used to verify the hypotheses of this study. Analyzed data reveals a positive relationship among sustainability development factors (i.e. environmental, economic, social aspects) and financial performance. Furthermore, the result of hierarchical multiple regression has shown that the moderating effect of transformational leadership is significant only on the relationship between Environmental aspects and financial performance. Also, the transformational leadership does not moderate the impact of "Economic aspects and Social aspects" on the financial performance. This work strengthens the previous findings in the available literature as to how sustainability practices enhance the construction firms' performance. Moreover, this study involves the moderating role of transformational leadership on the main relation which also proves and supports the existing knowledge on performance measurement and performance of organisations. This study also contributes to practical aspects, by providing contractors with insights into implementing sustainability practices and tools to measure the sustainable construction firms' performance.
\end{abstract}

Keywords: Sustainable development, Financial performance, Transformational leadership, Construction industry, Jordan.

\section{INTRODUCTION}

Sustainability is important to present and future generations, governments and organizations have become increasingly aware of global and local sustainability issues. The sustainability of companies depends on the application of environmental, economic, and social concepts, which reflect the viewpoints of governments or society. Companies may be unable to apply these three concepts due to a number of constraints, whether at the governmental or societal level.

Jordan, one of the developing countries in the Middle East, is located at the heart of a conflict-ridden and unstable region. Natural resources, particularly water, are scarce, a key issue in the business environment. Forced migration is one of the main demographics and political determinants with development implications. Being at the crossroads of two major areas of instability and prolonged conflicts, Jordan has become the destination for several waves of forced migrants, first from Palestine and lately from Iraq and Syria. Refugees continue to migrate to Jordan as the conflict in neighbouring countries has no foreseeable solution.

*Address correspondence to this author at the Faculty of Business, Arab Open University, Jordan; Tel: 009626 5630630: Ext:2112; Fax: 0096265630610; E-mail: ghazalatphd2014@gmail.com, a_ghazalat@aou.edu.jo

JEL Classification: P17, L20, L25, L74, Q56.
According to a study by the Arab Bank (2014), Jordan suffers from inadequate financial and natural resources, high unemployment rate, poverty, and high public debt, which, in turn, affects the implementation of sustainable development practices (SDP). Jordan has faced many obstacles during the implementation. Companies rarely implement SDP properly due to the lack of experience in implementation, observation, and evaluation of top management and quality departments in the Jordanian market, generally, and the construction sector, specifically.

As a developing country, Jordan is one of the fastest growing countries in the Arab region, and it has started promoting sustainable practices. Jordan officially participated in the World Summit for Environment and Development in Rio de Janeiro in 1992, where the country expressed its aim to achieve sustainable development for its positive effects on the development of social life, growth of the economy, and conservation of natural and environmental resources. However, attempts were not successfully completed due to the large growth of the population during the last decade as a result of forced migrations from neighbouring countries and high natural growth rate. The increase in the percentage of population makes achieving a balance between resources and population a challenging process, caused the environmental content's deterioration (GCEP, 2007). 
The issues of environmental dissatisfaction with construction projects have regularly appeared in media. The King of Jordan Abdullah II and the government have urged professional developers to implement proactive solutions to promote sustainable development within their domain and to be responsive to the need for better economic, environmental, and social protection (MOP, 2015). The decline in the performance of the Jordanian construction industry in recent years has resulted in an urgent need for them to strengthen their operations to face current and future challenges. JCCA (2014) asserts that the Jordanian construction industry should aim to initiate an industrydriven process of change and reform that will make the industry more sustainable, deliver high-quality products and reliable services, and become performanceoriented to have an enhanced image (JCCA, 2014). Alsubeh (2013) highlighted that construction in Jordan fails to integrate sustainability, which may cause construction industry to not function properly. If a country needs to be environmentally sustainable, the construction industry should also consider the social, environmental, economic, and political context of Jordan and propose solutions in response to these characteristics (Alsubeh, 2013). Unfortunately, in Jordan, the issue of sustainable housing development is still new, and no proactive solutions have been taken to develop the construction sector. General frameworks and indicators for the construction industry are lacking, and Key Performance Indicator (KPI) targeting sustainable practices are absent (Alkilani et al., 2013).

In this research paper, the study contributes to the existing literature by clarifying the aforementioned voids. First, the study suggests the effect of SDP on FP in construction industry. This would provide new insight into several approaches for effective practices of SD that are deemed significant for financial performance in the construction industry. Second, the study introduces the interaction effect between the three aspects of SDP and TL. This would reveal hitherto unknown relationships which should provide for actionable reference points for both practitioners and academicians.

\section{BACKGROUND \& HYPOTHESES DEVELOPMENT}

The financial performance of the construction industry in the developed and developing countries has been a source of worry for both industry practitioners and scholars. Several works emphasized performance improvement in the construction industry (Bassioni et al., 2005; Beatham, 2003; Kagioglou et al., 2001).
Obviously, construction companies lack effective and efficient methods of measuring their performance and identifying new best practices. The apparent incongruence among cross-cultural features and managerial differences shows the inapplicability of many of the identified performance models in different countries (Luu et al., 2008).

Studies on SDP and financial performance have shown mixed results in the past. Some studies have reported positive relationships between financial performance and SDP (Ağan et al., 2016; Bodhanwala \& Bodhanwala, 2018; Endrikat et al., 2014; Lucas \& Noordewier, 2016; Martínez-Ferrero \& Frías-Aceituno, 2015; Muhammad et al., 2015; Song et al., 2017) whereas in others, SDP was found to have partial effect on future levels of financial performance (Endrikat et al., 2014; Iwata \& Okada, 2011; Lucas \& Noordewier, 2016) or negatively related to financial performance (Horváthová, 2010, 2012; Song et al., 2017) Reviewing past empirical studies had shown that testing similar SDP dimensions led to different results on financial performance. For example, environmental management practices (EMP) were found positively related to financial performance among 941 publiclytraded manufacturing U.S. firms, (Lucas \& Noordewier, 2016). Similar findings were also found by Endrikat et al. (2014) where corporate environmental performance (CEP) was a positive and partially bidirectional relationship between CEP and corporate financial performance (CFP). In another study, Iwata \& Okada (2011) found partial effects of both waste emissions and greenhouse gas emissions on the financial performance of Japanese manufacturing firms from 2004 to 2008.

In other study, Ağan et al. (2016) have used the survey method, from Turkish manufacturing plants with more than 250 employees and tested the relationship between the environmental supplier development (ESD) and firm performance. They found that Corporate Social Responsibility (CSR) is positively related to the financial performance. Similar findings were also found by Martínez-Ferrero \& Frías-Aceituno (2015) where corporate social responsibility plays a significant role in FP for 1960 multinational non-financial listed companies from 25 countries for the period between 2002 and 2010. There was a positive bidirectional relationship between corporate social responsibility and $\mathrm{FP}$, where the use of market value indicated that investors are able to identify economic, social and environmental practices generating a positive effect on FP. 
Though in some studies, SDP has shown either positive or negative relationship with financial performance, mix results were also found when testing a study conducted on Chinese listed firms from 2007 to 2011, where environmental management was found that two methods of environmental protection, positively impact future financial performance. However, these measures also do not have a significant impact on the financial performance of the current year (Song et al., 2017). Similarly, in a study conducted by Muhammad et al. (2015) on publicly listed companies in Australia, reported significant positive relationship between environmental performance and financial performance before financial crisis period (2001-2007) and no relationship during the financial crisis (2008-2010).

The sample under a study conducted by Bodhanwala \& Bodhanwala (2018) consists of 58 Indian firms, as the study revealed a significant positive relationship between sustainability and firm performance measures (i.e. return on assets, return on investment, return on equity, and earnings per share). Empirical evidence suggests that firms that practice remarkable sustainable development strategies report higher profitability and have substantially low gearing level.

However, the environmental effect was found to be negatively related to financial performance in a study involving 552 industrial firms from 5 European countries (Horváthová, 2010). Similar findings were also found by Horváthová (2012) when tested data from the Czech Republic, where environmental performance was negatively related to financial performance, lagged by 1 -year lag, whereas, it became positive for 2 years lag.

In short, the mixed findings resulted from the kind of SDP dimensions tested in the study. Though past studies have shown mixed findings regarding the relationship between SDP and financial performance. Based on the above discussions, the following hypotheses are proposed:

H1: A positive relationship exists between sustainable development practices and financial performance of construction companies.

H1a: A positive relationship exists between social perspective and the ROA of construction companies.

H1b: A positive relationship exists between social perspective and the ROI of construction companies.
H1c: A positive relationship exists between social perspective and the SG of construction companies.

H1d: A positive relationship exists between environmental perspective and the ROA of construction companies.

H1e: A positive relationship exists between environmental perspective and the ROI of construction companies.

H1f: A positive relationship exists between environmental perspective and the SG of construction companies.

H1g: A positive relationship exists between economic perspective and the ROA of construction companies.

H1h: A positive relationship exists between economic perspective and the ROI of construction companies.

H1i: A positive relationship exists between economic perspective and the SG of construction companies.

Transformational leadership (TL) (Bass, 1985, 1999 ) is one of the most popular topics in leadership literature since it was established and developed by Bass in 1985 (Antonakis et al., 2003). Transformational leadership is defined as the ability of the leader to motivate and inspire followers and enable them to exceed current or standard levels of performance, thereby successfully influencing followers to aim efforts for higher organizational objectives and aspirations (Bass \& Riggio, 2006). Moreover, Avolio \& Yammarino (2013) defined transformational leadership as a set of procedures and behaviors that serve to maximize the performance of followers beyond expected levels and toward a common issue of the "greater good."

Though there is insufficient of research on the moderating effect of $T L$ that focusing on SDP and financial performance, transformational leadership appears to play a positive and statistically significant role individually and in a moderating sense in another context. For example, previous studies suggested that Investing in $T L$ development for managers could reduce emotional exhaustion and turnover (Green et al., 2013). In other studies, McCormick et al. (2018) said that transformational leaders who will inspire, motivate, and support employees behaviour; or innovation and flexibility which will create a strong condition that fosters proactivity of employees. Similarly, Engelen et al. (2015) found that; the performance consequences of entrepreneurial 


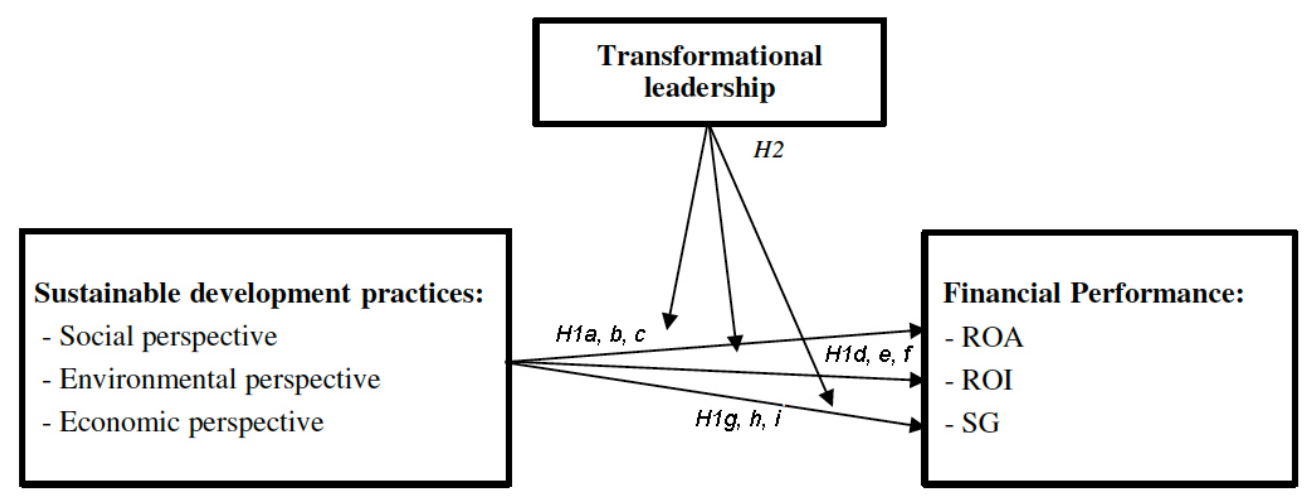

Figure 1: Theoretical framework.

orientation (EO) are greater when top management adheres the highest possible level of transformational behaviors.

Furthermore, TL also was found to moderate the relationship between Human Resource Management (HRM) practices and firm performance in Communication Technology (ICT) companies in Malaysia (Mansouri, 2016). Similar findings have also been reported in a study conducted by Nyachanchu et al. (2017), when they conducted a study on 271 manufacturing facilities.

Taken as a whole, these previous studies have provided a strong theoretical basis and expecting that TL would enhance creativity among followers.

The current study sought to extend this line of research to determine whether $T L$ have a moderating effect on financial performance. Given the lack of previous studies specifically on the impact of TL as a moderator on the relationship between SDP and financial performance, nevertheless, there were several previous studies examined the role of TL as a moderator variable and its impact on the relationship between different variables that have directly related to this study such financial and non-financial performance. Therefore, based on these premises, the following hypotheses are proposed:

H2: Transformational leadership exerts a moderating effect on the relationship between sustainable development practices and the financial performance of construction companies (see Figure 1).

\section{METHODOLOGY}

This study adopts the quantitative analysis in an attempt to investigate the relations between independent and dependent variables (Saunders et al., 2009). Thus, this study develops a structured questionnaire to collect data about each variable included in the suggested framework (Figure 1). This study adopts a well-developed item from previous research to measure proposed variables in this study.

According to statistics of JCCA the construction companies operating in Jordan located in all regions are 3060 , and they are classified into six categories. Construction companies registered under the JCCA were selected for this study (JCCA, 2017). Table 1 provides the total number of contractors for each category. As conducting a survey on all construction companies in all regions would be impractical, only one region was chosen. The Amman region was selected because its construction companies have the greatest number of contractors. The total population for this study was 1113 active contractors registered under JCCA from G1 to G6 in December 2017. The list of contractors was obtained from (JCCA, 2017).

Table 1: Distribution of Construction Companies in Jordan

\begin{tabular}{|c|c|c|}
\hline \multirow{2}{*}{ Region } & Company Category & $\begin{array}{c}\text { Total number of } \\
\text { contractors }\end{array}$ \\
\hline \hline \multirow{4}{*}{ Amman } & $\mathrm{G} 1$ & 89 \\
\cline { 2 - 3 } & $\mathrm{G} 2$ & 62 \\
\cline { 2 - 3 } & $\mathrm{G} 3$ & 115 \\
\cline { 2 - 3 } & $\mathrm{G} 4$ & 159 \\
\cline { 2 - 3 } & $\mathrm{G} 5$ & 237 \\
\hline \multirow{2}{*}{ Total } & $\mathrm{G} 6$ & 00 \\
\hline
\end{tabular}

The study approach involves the use of structured questionnaires which was considered to be the most appropriate tool to reach the population of the study especially when data required for the study can be obtained by the instrument. Respondents were 
randomly selected from management personnel of contractors, across the Amman district of Jordan.

A total of 290 questionnaires were distributed to the potential respondents but only 253 questionnaires were completed, returned and found suitable for use in the analysis. This represents a response rate of $87 \%$. These were measured on a five-point Likert Scale where 1 = strongly disagreed, $2=$ disagreed, $3=$ not sure, $4=$ agreed, and $5=$ strongly agreed. The literature review indicates that the present research includes sustainable development practices and financial performance of construction companies in Jordan. This study also examines the moderation effect of transformational leadership in these relationships. The theoretical framework integrates the three main aspects of sustainability (i.e., environmental, economic, and social). About fifty-three (53) items were adopted to capture the above dimensions of sustainable development, financial performance and about twentythree items (23) were adopted to measure the moderator variable transformational leadership. The data collected through questionnaires; this study is a cross-sectional as it describes the current situation of contractor companies in Jordan. In summary, this study is conclusive as it tests specific hypotheses and investigates specific relationships between variables.

\subsection{Items Measurement}

Positive and negative relationships are established through the independent and dependent variables (Sekaran \& Bougie, 2016), in addition to moderator variable ( $T L)$. This study has three main independent variables, namely, environmental, social and economic aspects,

- Social issues: we adopted questionnaire from Rashideh (2010) which included fifteen questions, nine for Ethics indicators, and six for Welfare indicators

- Environmental issues: we adopted seventeen questions (i.e. items) developed by Rashideh (2010) The number of questions used are eighteen; eight for Environmental impact, seven for Environmental efficiency, And three for Volunteer actions.

- Economic issues: The number of questions used are seventeen; nine for Financial indicators, and seven for Human capital indicators Items for each construct is adopted from several previous research (Rashideh, 2010).

- Financial performance: we employed three constructs to measure financial performance namely: ROA, ROI and SG. We adopted items for each construct from validated and reliable instruments used in extent (Al Sawalqa, 2011; Jessica et al., 2008).

- Transformational Leadership (TL): $T L$ is operationalized as a second-order construct, we employed twenty-three questions (23) were adopted to measure the moderator variable transformational leadership. All items are adopted from previous research (Bassioni et al., 2005; Gazali, 2012).

\section{DATA ANALYSIS}

For hypotheses testing this study uses statistical package for the social sciences (i.e. SPSS). The main analysis technique used in this study is factor analysis. Such analysis is applied to all factors in the sustainability practices and financial performance of contractors in Jordan as well as on the role of TL as a moderator on the relation. The general strategy involves testing the interaction by using hierarchical multiple regression to assess the effects of a moderating variable. To test moderation, we examined the interaction effect between the independent variable and moderator and whether such an effect is significant in predicting the dependent variable. The outcomes, i.e. the new factors from the factor analysis exercise, were then tested using one-way analysis of variance (ANOVA), Pearson correlation and regression analysis. To ensure the consistency of understanding, standardisation of the procedure and presentation of the achievement of all research objectives, this section reports the outcomes in the following manner: i) oneway ANOVA results, ii) correlation analysis results and iii) factor analysis and regression analysis results.

This study reviewed the sample characteristics and descriptive analysis of the survey data. The analysis of demographic characteristics of the respondents indicated that the sample of the study was relevant to achieve the objectives of the study. Regarding the individual demographic characteristics, the questionnaires were completed by directors or those in similar positions, such as the manager of the financial department, assistant financial manager, or executive. Table 2 indicates that $78.7 \%$ of respondents were 
Table 2: Background Information of Respondents

\begin{tabular}{|c|c|c|}
\hline \multicolumn{3}{|l|}{ Category of the Company } \\
\hline $\mathrm{G} 2$ & 12 & 4.7 \\
\hline G3 & 24 & 9.5 \\
\hline G5 & 51 & 20.2 \\
\hline G6 & - & - \\
\hline Total & 253 & 100 \\
\hline \multicolumn{3}{|l|}{ Position in Company } \\
\hline Project Manager & 34 & 13.4 \\
\hline Architect & - & - \\
\hline Engineer & 6 & 2.4 \\
\hline Others & - & - \\
\hline Total & 253 & 100 \\
\hline \multicolumn{3}{|l|}{ Academic Qualification } \\
\hline Secondary School & - & - \\
\hline Diploma & 9 & 3.6 \\
\hline$<5$ Years & 9 & 3.6 \\
\hline 5- 10 Years & 34 & 13.4 \\
\hline $11-15$ Years & 77 & 30.4 \\
\hline$>15$ Years & 133 & 52.6 \\
\hline Total & 253 & 100 \\
\hline \multicolumn{3}{|l|}{ Area of Specialization } \\
\hline Residential Buildings & 130 & 51.4 \\
\hline Commercial Buildings & 123 & 48.6 \\
\hline Industrial Buildings & - & - \\
\hline Bridges & - & - \\
\hline Roads & - & - \\
\hline Others & - & - \\
\hline Total & 253 & 100 \\
\hline Member of Professional Body & 253 & 100 \\
\hline Participation in social responsibility & 199 & 78.7 \\
\hline
\end{tabular}


directors and roughly $13.4 \%$ were project managers. This result supports the reliability of the collected data. Respondents were spread all over the Amman District of Jordan. Most companies are located in Amman City and its surrounding areas. However, the operations office might differ from the registered address due to the location of projects and other technical reasons.

Jordanian workers are well educated. Most respondents are technically and academically proficient. Among the respondents, 9 (3.6\%) passed their diploma level, approximately $209(82.6 \%)$ had a bachelor degree, $29(11.5 \%)$ had a master degree and $6(2.4 \%)$ were post-graduate degree Doctor of Philosophy (PhD) holders. Table 2 also shows that the respondents were highly experienced. In particular, $52.6 \%$ of the respondents had worked for more than 15 years, $30.4 \%$ had experienced between 11 and 15 years and the rest had experience of less than 10 years. Therefore, in many ways, these contractors could understand the concept and practices of sustainability. Survey respondents were mostly directors and project managers. Table 2 indicates that $51.4 \%$ of the sample is working in developing residential buildings and the remaining $48.6 \%$ works in developing commercial buildings. All respondents belong to a professional body and approximately $78.7 \%$ are members of different social responsibility bodies.

Prior to conduct and an examine of the regression analysis, we examined the distribution of the data by examining Skewness and Kurtosis for each variable. All values varied between the values of \pm 0.032 and \pm 1.62 , which are obviously below the cutoff value of \pm 2 (George, 2011). This indicates that our data set is normally distributed.

Statistical tests were conducted to evaluate the survey constructs, e.g. reliability, validity and correlation tests. The reliability test examines the degree to which individual items used in a construct are consistent with their measurements (Nunnally \& Bernstein, 1994). The validity test assesses the degree to which items are designed to load on the same construct (Carmines \& Zeller, 1979). Reliability was evaluated using a reliability coefficient of Cronbach's alpha. The internal reliability test indicated that all the constructs were in the acceptable range.

Tests of validity and reliability were applied to the variables of the study. Also, factor analysis was used to validate the scales of the different variables used in the study. Strong evidence was found for considering the variables of this study in the next stage to test the hypotheses.

Table 3: Reliability Coefficients (Cronbach Alpha) for Factors Used in this Study

\begin{tabular}{|c|c|}
\hline Variables & Cronbach's alpha \\
\hline \hline Sustainable development practices & 0.940 \\
\hline Environmental perspective & 0.966 \\
\hline Environmental Impact & 0.901 \\
\hline Environmental Efficiency & 0.927 \\
\hline Volunteer Action & 0.963 \\
\hline Economic perspective & 0.975 \\
\hline Financial Indicators & 0.953 \\
\hline Human Capital Indicators & 0.946 \\
\hline Social perspective & 0.958 \\
\hline Ethics Indicator & 0.919 \\
\hline Welfare Indicators & 0.942 \\
\hline Financial Performance & 0.792 \\
\hline
\end{tabular}

We established two structural models to examine our hypotheses including the main effect model (first model) and the interaction model (second model). The main effect model was designed to examine and test the hypotheses from $\mathrm{H} 1 \mathrm{a}$ to $\mathrm{H} 1 \mathrm{i}$. Meanwhile, the interaction model was proposed to examine the hypotheses related to the proposed moderation effects in $\mathrm{H} 2$. The results of the estimation of both models are offered in Tables 8 and $\mathbf{9 .}$

According to the reliability test results, all the Cronbach's alpha values are 0.825 and above 0.60 which indicates that all the measures are reliable. Bartlett's test of sphericity was significant $(p=0.000)$ and the value of KMO measure of sampling adequacy was 0.772 (Table 4) which suggests a sufficient number of significant inter-correlation of factor analysis.

Three measures of financial performance were selected (i.e., ROA, ROI, and SG). The correlation between the related measures is significant which suggests that the 3 measures constitute many factors. Table 4 presents the results of factor analysis on 3 items for the financial performance with factor loading ranging from 0.829 to 0.882 .

Table 5 shows that the relationship between variables ranges between low to high correlation and the high values reflects the high relationship between 
Table 4: Results of Factor Analysis for Financial Performance

\begin{tabular}{|c|c|c|c|}
\hline The variable & Variable dimensions & Item & Factor loading \\
\hline \hline \multirow{3}{*}{ Financial performance } & Return on assets & ROA & .829 \\
\cline { 2 - 4 } & Return on investment & ROI & .882 \\
\cline { 2 - 4 } & Sales growth & SG & .844 \\
\hline
\end{tabular}

Table 5: Pearson Correlation

\begin{tabular}{|c|c|c|c|c|c|c|c|c|c|c|c|c|}
\hline & 1 & 2 & 3 & 4 & 5 & 6 & 7 & 8 & 9 & 10 & 11 & 12 \\
\hline Environmental perspective (1) & 1 & & & & & & & & & & & \\
\hline Economic perspective (2) & .078 & 1 & & & & & & & & & & \\
\hline Social perspective (3) & $.225^{\star *}$ & .008 & 1 & & & & & & & & & \\
\hline Financial performance (4) & $.216^{* *}$ & $.222^{* *}$ & $.249^{\star *}$ & 1 & & & & & & & & \\
\hline Transformational Leadership (5) & $.189^{* *}$ & $.124^{*}$ & $.292^{* *}$ & $.256^{* *}$ & 1 & & & & & & & \\
\hline Environmental Impact (6) & $.977^{* *}$ & .072 & $.237^{* *}$ & $.232^{* *}$ & $.200^{* *}$ & 1 & & & & & & \\
\hline Environmental Efficiency (7) & $.974^{* *}$ & .072 & $.195^{* *}$ & $.195^{\star *}$ & $.178^{* *}$ & $.909^{* *}$ & 1 & & & & & \\
\hline Volunteer Action (8) & $.962^{* *}$ & .093 & $.229^{* *}$ & $.196^{* *}$ & $.156^{*}$ & $.929^{* *}$ & $.919^{* *}$ & 1 & & & & \\
\hline Financial Indicators (9) & .074 & $.978^{* *}$ & -.006 & $.207^{* *}$ & .075 & .059 & .081 & .087 & 1 & & & \\
\hline Human Capital (10) & .079 & $.977^{* *}$ & -.013 & $.223^{* *}$ & .076 & .063 & .090 & .080 & $.988^{\star *}$ & 1 & & \\
\hline Ethics Indicator (11) & $.245^{* *}$ & .024 & $.978^{* *}$ & $.269^{* *}$ & $.262^{* *}$ & $.259^{* *}$ & $.215^{* *}$ & $.247^{* *}$ & .010 & .002 & 1 & \\
\hline Welfare Indicators (12) & $.179^{* *}$ & -.014 & $.957^{* *}$ & $.203^{* *}$ & $.313^{* *}$ & $.190^{* *}$ & $.153^{*}$ & $.188^{* *}$ & -.028 & -.034 & $.876^{* *}$ & 1 \\
\hline
\end{tabular}

Note: * Correlation is significant at the 0.05 level; ${ }^{* *}$ Correlation is significant at the 0.01 level.

the variables. The Person correlation reveals that environmental, economic and social issues are significantly correlated $(p<0.01)$ with the extent of financial performance. Social aspects had a positive and significant relationship with the extent of financial performance $(r=0.24, p<0.01)$, suggesting that the high usage of social aspects is associated with usage of financial performance (i.e. financial performance measures). This result seems to imply that the contractors believe highly that implementing social aspects will generate better financial performance. Likewise, a weak positive and significant relationship ( $r$ $=0.216, p<0.01, r=0.222, p<0.01$ ) was found between environmental and economic aspects and the extent of financial performance. Therefore, companies with a high level of economic and environmental aspects experience better financial performance.

Concerning multicollinearity, the TOL values were between 0.944 and 0.994 , and the VIF values ranged from 1.006 to 1.059 (Table 6). Thus, no occurrence was found for any multicollinearity problem between the independent variables. The TOL and VIF values for the variables are within the acceptable limit to indicate no support for the existence of severe multicollinearity problems. Therefore, the results of the multicollinearity assumptions suggest fitness of the data of the survey conducted in this study.

Table 6: Collinearity Statistics Test

\begin{tabular}{|c|c|c|}
\hline Model & Tolerance & VIF \\
\hline \hline Environmental perspective & .944 & 1.059 \\
Economic perspective & .994 & 1.006 \\
\hline Social perspective & .949 & 1.053 \\
\hline
\end{tabular}

\subsection{Regression Results}

The statistics relating to the hypothesis $(\mathrm{H} 1)$ revealed that $R$, the correlation of the independent variables and the dependent variable, is (0.364) (see Table 7). Moreover, R Square (0.132) which is the explained variance, is the square of the multiple $R$ (0.364). The results indicate that $(13.2 \%)$ of the variance (R-Square) in the dependent variable has been significantly explained by the independent variables. Thus, the model is fit at a significant level of 
Table 7: Multiple Regression Results for Hypothesis a (H1)

\begin{tabular}{|c|c|c|c|}
\hline \multirow{2}{*}{ Independent variables } & Standardized Coefficients & \multirow{2}{*}{ S value } \\
\cline { 2 - 4 } & Beta & $2.508^{* * *}$ & .013 \\
\hline \hline Environmental issues & .152 & $3.525^{* * *}$ & $3.516^{* * *}$ \\
\hline Economical issues & .209 & .001 \\
\hline Social Issues & .213 & \\
\hline F- statistics & 12.664 & \\
\hline $\mathrm{R}$ & .364 & \\
\hline $\mathrm{R}^{2}$ & .132 & \\
\hline
\end{tabular}

${ }^{*},{ }^{* *},{ }^{* * *}=p$-value $>0.10,0.05,0.01$.

Table 8: Result of Regression Analysis for Main Model

\begin{tabular}{|c|c|c|c|c|c|c|}
\hline \multirow{2}{*}{ Independent variables } & \multirow{2}{*}{ Hypothesis } & Standardized Coefficients & \multirow{2}{*}{ t- value } & \multirow{2}{*}{$\mathbf{F}$} & \multirow{2}{*}{$\mathbf{R}^{2}$} & \multirow{2}{*}{ Adj. $R^{2}$} \\
\hline & & Beta & & & & \\
\hline \multirow[t]{3}{*}{ Social aspects } & $\mathrm{H} 1 \mathrm{a}$ & .280 & $4.621^{* * * *}$ & $21.354^{* * *}$ & .078 & .075 \\
\hline & $\mathrm{H} 1 \mathrm{~b}$ & .211 & $3.422^{* * *}$ & $11.710^{* \star *}$ & .045 & .041 \\
\hline & $\mathrm{H} 1 \mathrm{c}$ & .181 & $2.922^{* * *}$ & $8.540^{* \star *}$ & .033 & .029 \\
\hline \multirow[t]{3}{*}{ Environmental aspects } & $\mathrm{H} 1 \mathrm{~d}$ & .209 & $3.380^{* * *}$ & $11.426^{* * *}$ & .044 & .040 \\
\hline & $\mathrm{H} 1 \mathrm{e}$ & .177 & $2.852^{* * *}$ & $8.133^{* * *}$ & .031 & .028 \\
\hline & $\mathrm{H} 1 \mathrm{f}$ & .182 & $2.927^{* * *}$ & $8.567^{\star \star *}$ & .033 & .029 \\
\hline \multirow[t]{3}{*}{ Economic aspects } & $\mathrm{H} 1 \mathrm{~g}$ & .142 & $2.267^{* *}$ & $5.140^{* * *}$ & .020 & .016 \\
\hline & $\mathrm{H} 1 \mathrm{~h}$ & .242 & $3.957^{*+*}$ & $15.657^{* \star *}$ & .059 & .055 \\
\hline & $\mathrm{H} 1 \mathrm{i}$ & . 188 & $3.028^{* * *}$ & $9.168^{* * *}$ & .035 & .031 \\
\hline
\end{tabular}

${ }^{*},{ }^{* *},{ }^{* * *}=\mathrm{p}$-value $>0.10,0.05,0.01$.

the F-statistic $\left(F=12.664^{* * *}\right)$. The constant term of this model is positive and significant at ( $p$-value < 0.05). According to the coefficient table, the t-value for each independent variable (social, environmental, economic perspectives) are significantly positive at 0.05 level with the performance of construction companies.

The figures in Table 9 shows the result of the interaction model. As shown in the table, the interaction latent variable "Environmental aspects * TL" has a significant path coefficient $(\beta=0.377$, at $P<0.05)$, indicating that $T L$ has a moderating effect on the role of environmental issues. Accordingly, the researcher decides to accept the related hypothesis of environmental issues $(\mathrm{H} 1 \mathrm{~d})$. This would show that environmental issue is a more efficient practice when TL is prevailing behavior in construction companies. Figure 2 shows the relationship between SDP and financial performance under high and low levels of TL. This result implies that, with respect to average levels of TL and SDP, SDP coupled with TL exerts joint positive effects on financial performance. That meant that SDP was more predictive of financial performance as TL became stronger. The results also show that the interaction latent variable "Economic aspects * TL" and "Social aspects * TL" has an insignificant effect $(\beta=0.167),(\beta=.170)$ at $P>0.05$, respectively indicating that $T L$ has no moderation effect on the role of economic issues and social issues. Thus, the researcher makes a decision to reject the related hypotheses of social issues and economic issues $(\mathrm{H} 1 \mathrm{a}$, $\mathrm{H} 1 \mathrm{~g}$ ). In view of the above results, the claim that $T L$ has a moderating effect was partially supported.

In summary, our results showed that only Environmental aspects and TL have direct effects on FP in the construction sector in Jordan. Contrary to expectations, social and economic aspects have no effect on FP in the construction sector in Jordan. Additionally, the result shows that TL interacts significantly with Environmental aspects and thus the claim that $T L$ has a moderating effect was partially supported. 
Table 9: Regression Analysis Of Interaction Model

\begin{tabular}{|c|c|c|c|c|c|c|}
\hline \multirow{2}{*}{ Variables } & \multicolumn{2}{|c|}{ Model 3.1} & \multicolumn{2}{|c|}{ Model 3.2} & \multicolumn{2}{|c|}{ Model 3.3} \\
\hline & Coeff. & $\mathbf{t}$ & Coeff. & $\mathbf{t}$ & Coeff. & $\mathbf{t}$ \\
\hline \multicolumn{7}{|l|}{ SDP } \\
\hline Environmental aspects & .337 & 2.918 & & & & \\
\hline Economical aspects & & & .208 & 3.324 & & \\
\hline Social aspects & & & & & .195 & 2.953 \\
\hline \multicolumn{7}{|l|}{ Moderator variable } \\
\hline Transformational leadership & .327 & 4.186 & .312 & 4.126 & .280 & 3.512 \\
\hline \multicolumn{7}{|l|}{ Interactive between variables } \\
\hline Environmental aspects $* \mathrm{TL}$ & $.377^{\star *}$ & 2.531 & & & & \\
\hline Economical aspects $* \mathrm{TL}$ & & & .167 & 2.221 & & \\
\hline Social aspects $* \mathrm{TL}$ & & & & & .170 & 1.874 \\
\hline $\mathrm{R}^{2}$ & .117 & & .120 & & .111 & \\
\hline$\Delta \mathrm{R}^{2}$ & .023 & & .017 & & .013 & \\
\hline Sig. F change & 6.406 & & 4.932 & & 3.512 & \\
\hline
\end{tabular}

Model 3.1: Environmental issues; Model 3.2: Economic issues; Model 3.3: Social Issues.

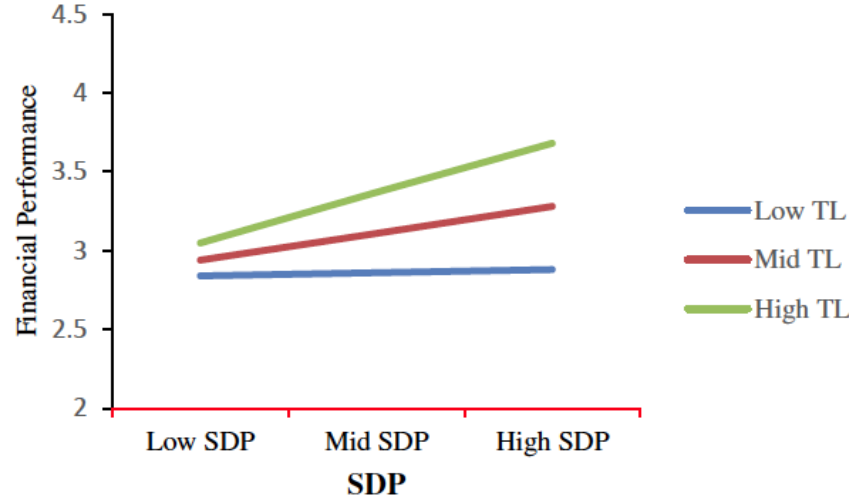

Figure 2: The Interaction Term between SDP and TL on Financial performance.

\section{DISCUSSION}

The main purpose of this study is to investigate the relationship between SDP and financial and nonfinancial performance. The study also examined the role of $T L$ as a moderator in the relationship between SDP and financial performance. Initially, several issues were raised related to the implementation of sustainability practices in the construction companies in Jordan. The findings of the study revealed that all components of environmental aspect, economical aspects, and Social aspects namely environmental impact, environmental efficiency, volunteer action; financial and human capital indicators; ethics and welfare indicators respectively were positively related to financial performance namely return on assets (ROA), return on investment (ROI), and sales growth
(SG). These current findings supported the past empirical study conducted by Tan et al. (2011). Furthermore, in their study, Ittner et al. (2003) found that firms making extensive use of a broad set of financial and non-financial measures (i.e. measurement diversity approach) than firms with similar strategies have higher measurement system satisfaction and stock market return. The study also found little evidence that strategic performance measurement practices are associated with ROA and sales growth (SG).

This study investigated the relationships between the sustainability factors and the financial performance of construction firms among contractors. The results suggest that there were positive associations between the practicing of sustainable factors represented by the (environmental aspect, economic aspect and social aspect) and financial performance of contractors in Jordan. These phenomena suggest that the Jordanian contractors perceived that the awareness and practicing of sustainability factors lead to better performance of their firms. The findings of this study also disclosed that the environmental aspect, economic aspect, and social aspect, could explain and enhance the financial performance of contractors in Jordan.

Also, the results found that the perceptions of these contractors towards sustainability factors and financial performance were almost equal. Therefore, it helps to explain and provide evidence that the ultimate goal of 
the practicing of sustainability practices, in this case, is to ensure continuous improvement that leads to better performance of the organization. Although these results could be predicated, however, it provides evidence in many ways that the practicing of sustainability helps to improve the financial performance_of contractors.

Based on the survey conducted in the field work, the proposed model is proven statistically applicable and relevant in the Jordanian context. This study was successfully managed to conceptualize the development of a multidimensional assessment framework/model for sustainability and financial performance in the Jordanian construction industry. The multiple regression analysis showed that all the variables could significantly predict the financial performance.

Consequently, a positive relationship exists between sustainable development practices and the financial performance of construction companies. Also, according to the coefficient results, it is found that $\boldsymbol{t}$ _value for each independent variable (social perspective, environmental perspective, economic perspective) are significant at 0.05 level, that means a positive relationship exists between $\mathrm{SD}$ and the financial performance of construction companies.

However, we estimated the interaction model to examine our moderating hypotheses. Our results show that the interaction effect of TL is positively related to environmental issues and financial performance in construction sector. This would suggest that TL can be seen as a facilitating condition to the role of SDP. Additionally, $T L$ is a critical key that managers can use to direct their firms toward financial performance. Contrary to the expectations, the moderate role of $T L$ between (economic and social issues) and financial performance was not confirmed. This indicates that the effects of economic and social issues on financial performance mainly depends on leader's abilities in creating positive psychological capabilities and a positive ethical climate in their organisation than on the prevalent TL practices and instructions.

\section{THEORETICAL AND PRACTICAL IMPLICATION}

This study adopted variables from the sustainability concept, including environmental, economic and social aspects. The major contribution of this work is the ability to highlight and integrate the concept of sustainability into the sustainable construction firms' performance among contractors in
Jordan. This study also provides statistical and empirical evidence that sustainability practices are relevant, valid and applicable in the construction industry. This study contributes to the available sustainability literature as to how contractors, as one of the players in the Jordanian construction industry, implement sustainability practices in their organisations. This study applies stakeholder theory to build the performance model for construction companies. The stakeholder frame is the most relevant environment and cultural context to improve the impact on the performance of construction companies. In the Jordanian context, this work contributes to the body of knowledge by highlighting issues and identifying gaps in the scarcity of literature with the construction industry. In terms of theoretical contribution, this study proves and supports the existing knowledge on performance measurement and performance of organisations. The findings revealed that the measures of sustainable construction performance of an organisation are not based on the financial performance aspects only, also, other measurements of business success occur, such as contribution to society, safety awareness and environmental awareness.

In addition, practitioners can benefit from this study in several ways. Examples include the authorities, companies, consultants, relevant individuals and personnel involved in the Jordanian construction industry. The findings of this study provide insights to clear scepticism among contractors in Jordan about the implementation of sustainable construction. The findings revealed that sustainable construction firms' performance measurement also consists of other factors that are unrelated to financial aspect performance. This study also provides examples for other players in the construction industry, such as architects, engineers and suppliers, to consider sustainable practices in construction project development, design and execution. Thus, the current study findings have implications and recommendations for practitioners (both managers and accountants) to improve their performance measurement systems. This study provides more insight for practitioners regarding the influence of TL styles on interpersonal hierarchical SDP. This information becomes increasingly important as sustainable development becomes increasingly prevalent.

Finally, both academics and practitioners in the Jordanian construction companies must cooperate to improve management accounting practices in general 
and performance measurement practices in particular. Applied research should be completed, and practitioners should actively participate in conferences, workshops and related activities.

\section{LIMITATIONS OF THE STUDY}

Indeed, we rarely find a study without limitations. Similarly, this study includes some limitations as described below:

- The respondents involve one person per organisation. Capturing all aspects in the organisation, such as psychological problems that the staff in the company may encounter, seems unfeasible.

- The questionnaire used a five-point scale. The respondents were required to provide their perceptions by answering questions in the questionnaires. Perceptions from respondents seem to vary in considering a problem that they may encounter, in perceiving the statements and in respondents' feelings.

- $\quad$ The quantitative approaches were adopted in the study design and data analysis. A disadvantage of this approach involves being unable to translate human feelings or perceptions into numbers, but this approach is acceptable in subjective measurement.

- The choice of samples to determine the implementation of sustainability practices and sustainable construction firms' performance was assessed according to the opinions of the respondents. Therefore, bias could occur in the findings that are in favour of the contractors.

- Data collected in this study to measure the financial performance of contractors were obtained from the perceptions of the contractors. Formal records and documents of company's profit, ROA, ROI and return on sales were disregarded. Therefore, comparison of the perception of contractors towards financial performance could not be cross-checked with the actual performance of contractors, especially in the financial aspects of firm performance.

\section{FUTURE RESEARCH}

This study was limited to small and medium construction companies in Jordan. A wider different sector may be examined to improve the generalisability of the findings and validate the research instrument. In addition, further research may investigate the extent of using some relevant multiple measures among the big construction companies. Similar studies can also be conducted in other countries, particularly in developing countries in the Middle East and other regions.

Finally, future research should embark into investigating the impact of implementing sustainable practice to the construction industry in Jordan. These efforts should also compare the financial performance of contractors according to the perceptions of these companies as well as their actual achievements. As such, the mix-method approach in the research design should be considered in studying these impacts on contractors.

\section{REFERENCES}

Ağan, Y., Kuzey, C., Acar, M. F., \& Açıkgöz, A. (2016). The relationships between corporate social responsibility, environmental supplier development, and firm performance. Journal of Cleaner Production, 112, 1872-1881. https://doi.org/10.1016/j.jclepro.2014.08.090

Al Sawalqa, F. A. H. (2011). The changing role of management accounting: assessment of the impact of financial and nonfinancial performance measures usage on organizational performance in Jordan. Murdoch University.

Alkilani, S. Z., Jupp, J., \& Sawhney, A. (2013). Issues of construction health and safety in developing countries: a case of Jordan. Construction Economics and Building, 13(3), 141-156. https://doi.org/10.5130/AJCEB.v13i3.3301

Alsubeh, M. A. (2013). A strategic framework for sustainable construction in Jordan. Civil and Environmental Research, 3(2), 102-107.

Antonakis, J., Avolio, B. J., \& Sivasubramaniam, N. (2003). Context and leadership: An examination of the nine-factor full-range leadership theory using the Multifactor Leadership Questionnaire. The Leadership Quarterly, 14(3), 261-295. https://doi.org/10.1016/S1048-9843(03)00030-4

Arab Bank. (2014). Sustainability Report (2014). Retrieved from https://www.arabbank.com/docs/default-source/sustainabilityreports/sustainability-report-2014

Avolio, B. J., \& Yammarino, F. J. (2013). Introduction to, and overview of, transformational and charismatic leadership Transformational and Charismatic Leadership: The Road Ahead 10th Anniversary Edition (pp. xxvii-xxxiii): Emerald Group Publishing Limited. https://doi.org/10.1108/S1479-357120130000005005

Bass, B. M. (1985). Leadership and performance: New York: free press.

Bass, B. M. (1999). Two decades of research and development in transformational leadership. European journal of work and organizational psychology, 8(1), 9-32. https://doi.org/10.1080/135943299398410

Bass, B. M., \& Riggio, R. E. (2006). Transformational leadership: Psychology Press. https://doi.org/10.4324/9781410617095

Bassioni, H. A., Price, A. D., \& Hassan, T. M. (2005). Building a conceptual framework for measuring business performance in construction: an empirical evaluation. Construction management and economics, 23(5), 495-507. https://doi.org/10.1080/0144619042000301401 
Beatham, S. (2003). Development of an integrated business improvement system for construction. (c) Simon Beatham.

Bodhanwala, S., \& Bodhanwala, R. (2018). Does corporate sustainability impact firm profitability? Evidence from India. Management decision. https://doi.org/10.1108/MD-04-2017-0381

Carmines, E. G., \& Zeller, R. A. (1979). Reliability and validity assessment (Vol. 17): Sage publications. https://doi.org/10.4135/9781412985642

Endrikat, J., Guenther, E., \& Hoppe, H. (2014). Making sense of conflicting empirical findings: A meta-analytic review of the relationship between corporate environmental and financial performance. European Management Journal, 32(5), 735751. https://doi.org/10.1016/j.emj.2013.12.004

Engelen, A., Gupta, V., Strenger, L., \& Brettel, M. (2015). Entrepreneurial orientation, firm performance, and the moderating role of transformational leadership behaviors. Journal of management, 41(4), 1069-1097. https://doi.org/10.1177/0149206312455244

Gazali, H. A. (2012). The Impact of Transformational Leadership on Decision Taking Process Effectiveness in the Jordanian Insurance Companies, . MEU, Jordan.

GCEP. (2007). (The General Corporation for the Environment Protection), Ministry of Environment: A strategic overview. Jordan. Retrieved from https://gcep.stanford.edu/news/ articles2007.html

Green, A. E., Miller, E. A., \& Aarons, G. A. (2013). Transformational leadership moderates the relationship between emotional exhaustion and turnover intention among community mental health providers. Community mental health journal, 49(4), 373-379. https://doi.org/10.1007/s10597-011-9463-0

Horváthová, E. (2010). Does environmental performance affect financial performance? A meta-analysis. Ecological Economics, 70(1), 52-59. https://doi.org/10.1016/j.ecolecon.2010.04.004

Horváthová, E. (2012). The impact of environmental performance on firm performance: Short-term costs and long-term benefits? Ecological Economics, 84, 91-97. https://doi.org/10.1016/j.ecolecon.2012.10.001

Ittner, C. D., Larcker, D. F., \& Randall, T. (2003). Performance Implications of Strategic Performance Measurement in Financial Services Firms. SSRN Journal SSRN Electronic Journal. https://doi.org/10.2139/ssrn.395824

Iwata, H., \& Okada, K. (2011). How does environmental performance affect financial performance? Evidence from Japanese manufacturing firms. Ecological Economics, 70(9), 16911700. https://doi.org/10.1016/j.ecolecon.2011.05.010

JCCA. (2014). (Jordan Construction Contractors Association). Annual Report 2014, Amman, Jordan. Retrieved from (http://jcca.org.jo)

JCCA. (2017). (Jordan Construction Contractors Association). Annual Report 2017, Amman, Jordan. Retrieved from (http://jcca.org.jo)

Jessica, J. F., MCSM. D. C, \& Bausman. (2008). "Customer Satisfaction Survey, Best Practices".
Kagioglou, M., Cooper, R., \& Aouad, G. (2001). Performance management in construction: a conceptual framework. Construction management and economics, 19, 85-95. https://doi.org/10.1080/01446190010003425

Lucas, M. T., \& Noordewier, T. G. (2016). Environmental management practices and firm financial performance: The moderating effect of industry pollution-related factors. International Journal of Production Economics, 175, 24-34. https://doi.org/10.1016/j.ijpe.2016.02.003

Luu, T. V., Kim, S. Y., Cao, H. L., \& Park, Y. M. (2008). Performance measurement of construction firms in developing countries. Construction management and economics, 26(4), 373-386. https://doi.org/10.1080/01446190801918706

Mansouri, N. (2016). Moderating role of the transformational leadership in the relationship between HRM practices and performance: a study of ICT companies of Malaysia. Asian Social Science, 12(7), 1 https://doi.org/10.5539/ass.v12n7p1

Martínez-Ferrero, J., \& Frías-Aceituno, J. V. (2015). Relationship between sustainable development and financial performance: international empirical research. Business Strategy and the Environment, 24(1), 20-39. https://doi.org/10.1002/bse.1803

McCormick, B. W., Guay, R. P., Colbert, A. E., \& Stewart, G. L. (2018). Proactive personality and proactive behaviour: Perspectives on person-situation interactions. Journal of occupational and organizational psychology. https://doi.org/10.1111/joop.12234

MOP. (2015). Jordan's Way to Sustainable Development. Retrieved from http://www.mop.gov.jo

Muhammad, N., Scrimgeour, F., Reddy, K., \& Abidin, S. (2015). The relationship between environmental performance and financial performance in periods of growth and contraction: evidence from Australian publicly listed companies. Journal of Cleaner Production, 102, 324-332. https://doi.org/10.1016/j.jclepro.2015.04.039

Nunnally, J. C., \& Bernstein, I. (1994). Psychometric Theory (McGraw-Hill Series in Psychology) (Vol. 3): McGraw-Hill New York.

Nyachanchu, T. O., Chepkwony, J., \& Bonuke, R. (2017). Role of Dynamic Capabilities in the Performance of Manufacturing Firms in Nairobi County, Kenya. European Scientific Journal, ESJ, 13(31). https://doi.org/10.19044/esj.2017.v13n31p438

Rashideh, W. (2010). The development of assessment framework for construction firm's sustainability. University Sains Malaysia.

Saunders, M., Lewis, P., \& Thornhill, A. (2009). Research methods for business students: Pearson education.

Sekaran, U., \& Bougie, R. J. (2016). Research Methods For Business: A Skill Building Approach Seventh Edition: John Wiley \& Sons.

Song, H., Zhao, C., \& Zeng, J. (2017). Can environmental management improve financial performance: An empirical study of A-shares listed companies in China. Journal of Cleaner Production, 141, 1051-1056. https://doi.org/10.1016/j.jclepro.2016.09.105

Tan, Y., Shen, L., \& Yao, H. (2011). Sustainable construction practice and contractors' competitiveness: A preliminary study. Habitat Int. Habitat International, 35(2), 225-230. https://doi.org/10.1016/j.habitatint.2010.09.008

\section{DOI: https://doi.org/10.6000/1929-7092.2019.08.51}

(c) 2019 Jundi et al.; Licensee Lifescience Global.

This is an open access article licensed under the terms of the Creative Commons Attribution Non-Commercial License (http://creativecommons.org/licenses/by-nc/3.0/) which permits unrestricted, non-commercial use, distribution and reproduction in any medium, provided the work is properly cited. 